\title{
Factors Influencing Consumer Behavior: A Case of Television Buying in Nepalese Market
}

\author{
Bharat Rai \\ Assistant Professor, Nepal Commerce Campus, Tribhuvan University
}

\begin{abstract}
The purpose of the study is to investigate the effect of product quality, perceived price and social factors on buying decision in the buying of Television set in Nepalese market. Primary data were collected through structured questionnaire in the five point Likert scale. Convenient sampling was used and Kathmandu was the sampling location. 500 questionnaires were distributed to television users among them 394 questionnaires were collected. SPSS software has been used to processing and analyzes the data. Mean, Standard Deviation, Correlation and Regression techniques have been used to analyze the data. The research paper found that there is significant relationship between independent variables and dependent variable consumer behavior. There is significant and positive influence of product quality and perceived price and social factors on consumer behavior in television buying in Nepalese market.
\end{abstract}

Keywords: Consumer Behavior, Product Quality, Perceived Price, Social Factors

DOI: $10.7176 / \mathrm{EJBM} / 12-21-08$

Publication date:July $31^{\text {st }} 2020$

\section{Background of the study}

The TV set was historically considered luxury items. Nowadays television is becoming a must. Today Television has become an integral part of nearly every household and person. Television or television has emerged as a significant source of news, facts, and entertainment.

The consumer behavior refers to the behavior that consumer displayed in searching for, purchasing, using, evaluating and disposing of products and service that they expect will satisfy their needs. Consumer behavior is an individual's psychological factors which make the difference in the purchase of any goods, services and everything else. The consumer's behavior depends upon several factors that are very important to any marketing strategy team of any company or organization that targets customers directly. Consumer behavior study involves the assessment, search, purchase, consumption, and post-purchase behavior of consumers, and the disposal of purchased products that take into account environment and personal characteristics. This is the body of information that examines different aspects of the individual's purchasing and consumption of goods and services. The American Marketing Association ( AMA) defines consumer behavior as the dynamic interaction of cognition , behavior \& environmental events through which humans exchange aspects of their lives with different social and psychological variables at play.

Customer behavior requires an analysis of the spectrum of consumer desires, behaviors, and purchasing motivation (Borden, 1964).

Consumer behavior is the study of the process involved in selecting, buying, using or disposing of products, services, ideas or experiences for satisfying needs and desires by individuals or groups (Solomon et al, 2006).

Consumer behavior is the study of how individuals, groups and organizations select, puerchase, use and dispose of goods, services, ideas or experiences in order to satisfy their needs and wishes (Kotler \& Keller, 2006). Market research offers information to enhance or implement products and services, pricing, channel design, branding, and other marketing practices (Kotler, et al., 2008).

Purchasing intention can be described as a forward-looking plan to buy certain goods or services in the future; this plan does not always lead to action because it is influenced by performance capacity (Warshaw \& Davis 1985). Purchase intention is personal action tendencies relating to the product (Bagozzi et al. 1988).

Buying intentions means buying actions of the customer after he / she has considered and measured the product. The conduct can be used as a crucial point to predict consumer purchasing habits and their subjective intentions (Keller 2001). Researcher combined some studies on buying behaviors with decision-making processes for consumers. The outcome was that when consumers choose one good, their goal depended on the final decision.

Hence, most advertisers think purchasing intention of customers is a successful method of predicting purchasing. The intention to purchase shows customers preference to buy the product, the image of which is very close to customer. Moreover customers are well aware of certain brand name through advertising, publicity, from their past experience or information received from their friends and relatives (Teng, 2008).

Purchase intentions are personal action tendencies relating to the product (Bagozzi et al. 1979). Intentions are different from attitudes where attitudes are summary evaluations; intentions represent the person's motivation in the sense of his or her conscious plan to exert effort to carry out a behavior (Eagly \& Chaiken 1993). In Fishbein \& Ajzen's (1975) formulation, attitudes influence behavior through behavioral intentions. Past studies indicate 
that the link between attitude toward the object and behavior is not always clear. In some cases, attitudes have a direct effect on behaviors (Bagozzi \& Warshaw 1992) but no effect in Bagozzi (1992).

Ghosh (1990) tried to combine some studies about purchasing behaviors with consumers' decision-making processes. The result was that when consumers choose one goods, the final decision depended on their intention. Therefore, most marketers think consumers' purchasing intention is an effectively method of predicting purchasing.

The intention of a consumer to purchase a particular brand can be defined as his willingness to buy that brand. After being exposed to a TV commercial, a consumer might be interested about the product but being just interested in a product does not mean that the consumer has the intention to buy the product.

\section{Literature of the study}

Literature review refers to the study of previous studies of others. In the paper there are many factors which influence on purchase intention and among them perceived price, product quality and brand image has been taken as independent variables to examine the impact on purchase intention.

\section{Product Quality}

A consumer's opinion about overall product excellence or superiority is determined by perceived quality (Zeithaml, 1988). Quality is considered higher for durable products according to Lutz (1986), if the product can be checked before purchase. In other words, the greater the proportion of attributes that can be measured before purchase (search attributes) than those that can be measured only during use (experience attributes), the higher the perceived price for durable, industrial products.

A perceived price is one factor which can influence the willingness to purchase. The higher the perceived price the greater the chance it will lead to the desire to purchase and the decision to buy. Perceived quality is the consumer's perception of a product or service's overall quality or superiority with respect to the intended intent, in relation to alternatives (Aaker 1991). Consistency was seen as one of the brand-value dimensions (Aaker 1996).

Perceived quality is not the objective standard of the product but rather the subjective interpretation of the demand for the product (Zeithaml , 1988). It is a business imperative and today a lot of companies have turned quality into a powerful strategic asset driven by the customer. We build loyalty and trust for our customers by ensuring that consumers' needs and quality standards are met consistently and profitably. Zeithaml (1988) argued that the desire of the consumers to buy would be influenced by fair demand, price perception and value perception.

The perceived quality on the label impacts the decision-making process for a customer's purchase. That also has a big impact on brand loyalty for customers. Perceived consistency has a greater effect on the procurement process and brand loyalty of a company. When consumers are in a position that makes them unable to carry out a review of the product, the impact is very significant.

\section{Perceived Price}

Price is the worth or amount of money lost to receive a particular good or service. Price is the interest which is traded for what. Perceived price can be explained as the monetary amount above the average price received by multiple firms that sell a perfectly duplicated product over a finite time period (Ba \& Pavlou, 2002).

Perceived price can be defined as the perceptual representation of the consumer, or subjective perception of the product's objective price (Jacoby \& Olson, 1977). Although objective price is often factor support for this finding, its association with quality value and purchasing intention, perceived price has been established as a important intermediate variable in the relationship between market quality and value (Zeithaml 1988).

Intention to purchase tends to decrease when the actual price of products is higher than the acceptable price range and vice versa (Dodds, 1991). If the price range is below reasonable price range consumers are thought to lose trust in the quality of the product (Peter, 1969).

Economically sound shoppers typically regard prices as an essential component of financial costs (Zeithaml 1988). The perceived price, therefore, is the degree to which customers assume he has to pay in money to purchase the commodity.

Researchers have found, according to Chang \& Wildt (2006), that perceived quality and perceived price is significantly associated in the expected direction, and perceived quality is significantly associated with the intention to buy. Other authors support this finding, and found that perceived price influences the purchase intention (Moroe \& Chapman, 1987; Zeithaml , 1988).

\section{Social influence}

Increasing the social impact may come from peers, coworkers, family members and spouse when purchasing a Young Generation Smartphone. According to a study, buying behavior from consumers is influenced by others, particularly family members when buying highly involved goods (Farzana, 2012). A study has also found that there is a substantial relationship between social influence and dependence on a Smartphone for students (Ding et al., 2011). 
Another study of young adults in Malaysia between the ages of 19 and 25 shows that both direct and vicarious role models influence the consumer's intention to purchase, in which direct role model refers to parents and vicarious role model refers to celebrities. Prominent individuals therefore show greater control than parents (Ernest et al., 2010). Social influence indeed plays an important role and is the most influential part of the smartphone dependence of the student (Suki \& Suki, 2013).

According to Rashotte (2007), social influence is about the other person, emotions, attitudes, thoughts and actions shifting, deliberately or unintentionally affected. It's because of contact with other people who know each other, including parents and peers. Media, parent, and peers would influence consumers to buy the Smartphone (Nelson \& McLeod, 2005). Online experiences have an immense influence on customer behaviours. Everybody has someone else, who affects their buying decisions. Key social factors include benchmarks, family, location, and status (Perreau, 2014). Family members may influence individual customer purchasing behaviour. A family shapes the environment for an individual to learn creeds, to form and shape personality. This climate enables attitudes and viewpoints to be established on various topics such as social affairs, culture, and politics. A family creates first impressions of brands or products, and consumer preferences (Kotler \& Armstrong 2010; Khan 2006).

\section{Objectives of the Study}

This study aims to explore the association between factors affecting on buying behavior taking the reference of Television.

- To identify the factors influencing consumer behavior for buying of Television set in Nepalese market.

- To examine the relationship between the perceived price, product quality and social factors with consumer buying behavior of consumers in buying Television set in Nepalese market.

- To examine the impact of independent variables on consumer behavior.

\section{Conceptual Framework}

Based on the review of available literature in the field of purchase intention, the following framework has been developed to undertake the study in systematic manner.

\section{Diagram of the Conceptual Framework}

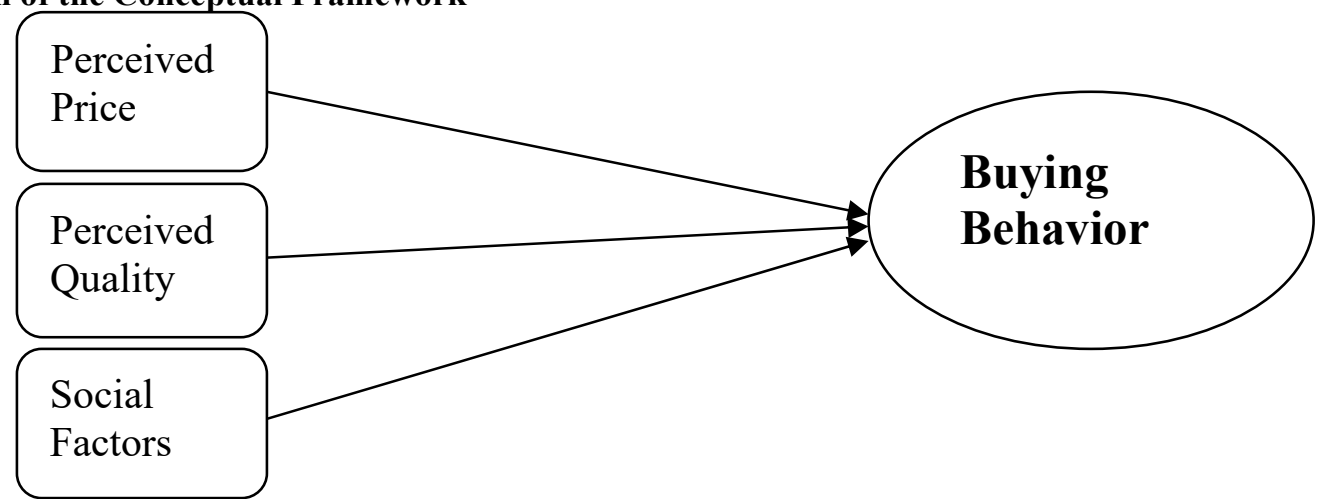

\section{Research Hypothesis}

H1: There is significant impact of perceived price on buying behavior in buying Television.

H2: There is significant impact of product quality on buying behavior in buying Television.

H3: There is significant impact of social factors on buying behavior in buying Television.

\section{Benefits of study}

It is expected that, the result of the study will increase the insight in theory and practice as well as reference and ideas for similar type of studies. The result of the study can be as reference for the company to increase the sales and formulate the marketing strategy with reference to the product quality, product price and social factors on consumer buying behavior.

\section{Research Methodology and Data Analysis}

Research methodology covers the type of research design used for undertaking population and sample, sampling process, source of data, data collection procedures and analytical tools used to analyze the data and develop the relationship between factors influencing consumer buying behavior.

Research design is an overall framework or plan for the activities to be undertaken during the course of research activities. 
The research design of the study has been used descriptive and causal based on primary data. Using survey methodology, structured 5 point Likert scale questionnaires on each dependent variable and independent variables has been administered to obtain responses from Television buyer Nepalese market.

Primary data has been collected from Television buyers in Nepalese market. The population of the study is the consumers who purchase the Television in Nepalese market and who are resident in Kathmandu valley.

Convenient sampling method has been used in the study. The sampling location for the research has been allocated at different show rooms, colleges and houses in Kathmandu valley. Five hundreds of questionnaire was distributed to the respondents but among them only 394 usable responses were collected. According to Cochran (1963) the sample must be at least 384 in the indefinite population. So, the sample size of the study is the 394.

Collected data has been analyzed by using mean, standard deviation to describe the consumers' buying behavior. Pearson Correlation Coefficient and Multiple Regression Analysis have been used to find out relationships between antecedent's factors and consumer buying behavior and influence of these factors on consumer buying behavior.

Cronbach's alpha coefficients have been utilized to measure the reliabilities and internal consistencies of the scales used.

\begin{tabular}{ccc}
\hline Table no. 1: Reliability Test & & \\
\hline Variables & Cronbach Alpha & Result \\
\hline Perceived Price & 0.809 & Good scale \\
Product Quality & 0.622 & Good scale \\
Social Factors & 0.860 & Good scale \\
Buying Behavior & 0.875 & Good scale \\
\hline
\end{tabular}

From the reliability analysis all factors were found to be of good reliability with the Cronbach's alpha value of above 0.6 for all the variables used under the study, which supports the reliability about the questionnaires which the researcher has developed. According to George \& Mallery (2010) the value of alpha is $\alpha>0.9=$ Excellent, $\alpha>0.8=$ Very Good, $\alpha>0.7=$ Good,$\alpha>0.6=$ Acceptable,$\alpha>0.5=$ Poor and unacceptable.

\begin{tabular}{ccccccc}
\hline \multicolumn{7}{l}{ Table 2: Descriptive Statistics and Correlation Analysis } \\
\hline Variables & Mean & S. D. & BB & PR & PQ & SF \\
\hline BB & 2.71 & 0.483 & 1 & & & \\
PP & 2.67 & 0.699 & 0.476 & 1 & 1 & \\
PQ & 2.6 & 0.537 & 0.719 & 0.324 & 0.402 & 1 \\
SF & 2.87 & 0.764 & 0.452 & 0.800 & 0.400 \\
\hline
\end{tabular}

All the variables were rated on the behavior intention scale with a score of 1 indicating strongly disagree, 2 indicating disagree, midpoint 3 indicating unsure (neutral), 4 indicating agree and score of 5 indicating strongly agree. The above table indicates that the mean score of social factors, product quality and perceived price are 2.87, $2.60,2.67$ and buying behavior is 2.71 respectively. All the value of variables is more than neutral value 2.5. So, all the responses are inclined towards agree and strongly agree of consumer buying behavior. When analyzing standard deviation, it is important to note that a significantly large value of standard deviation means that the data being tested is far away from the mean whereas a smaller value means that the tested variable is closer to mean. Likewise, the standard deviations have been recorded to be ranging from 0.483 to 0.764 which are consistent. It shows that the variability of data collected is significant to be used for the purpose of study. So, it is concluded that three independent variables effect on consumer buying behavior in the television buying in Nepalese market.

The above table describes also about correlation matrix between variables under investigation. It shows that there is significant positive relationship between perceived price and consumer buying behavior $(r=0.373, p<$ $0.000)$, product quality and consumer buying behavior $(\mathrm{r}=0.815, \mathrm{p}<0.000)$, social factors and consumer buying behavior $(r=0.422, p<0.000)$ at five percent level, for buying television to Nepalese market. So, all the independent variables have significant positive relationship with consumer buying behavior in the television buying in Nepalese market.

Multiple regression analysis

Multiple regressions have been conducted to identify the impact of product quality, perceived price and social factors on consumer buying behavior.

\begin{tabular}{rcc}
\hline Table 3: $\mathbf{R}^{2}$ test result & & Result \\
& Test & \multicolumn{2}{c}{$\mathbf{R}^{2}$} & & 0.648 \\
\hline Table 4: ANOVA test result & & Significant \\
Test & $\mathbf{F}$ & 0.000 \\
\hline ANOVA & 156.431 & \\
\hline
\end{tabular}


Table 5: Result of Coefficients

\begin{tabular}{llllllll}
\hline Model & \multicolumn{2}{l}{ Unstandardized Coefficients } & \multicolumn{3}{l}{ Standardized Coefficients } & \multicolumn{4}{c}{ Collinearity Statistics } \\
& $\mathrm{B}$ & Std. Error & Beta & $\mathrm{T}$ & Sig. & Tolerance & VIF \\
\hline (Constant) & .124 & .091 & & 1.55 & .121 & & \\
Product Quality & .656 & .031 & .770 & 24.52 & .000 & .839 & 2.192 \\
Perceived Price & .394 & .048 & .094 & 1.960 & .049 & .360 & 2.28 \\
Social Factors & .431 & .041 & .037 & .756 & .005 & .337 & 2.628 \\
\hline
\end{tabular}

a. Dependent Variable: Consumer buying behavior

The impact of all these three independent variables is tested together on dependent variable (consumer buying behavior). From the model summary the value of $\mathrm{R}$-square $=0.648$. It indicates that these three independent variables can explain approximately $64.8 \%$ of the proportion of variance of dependent variable, consumer buying behavior. However, it is still left $35.2 \%$ unexplained by these independent variables in the study and remaining unexplained percentage would be explained by others remaining variables. The value of $\mathrm{R}$ ranges from 0 to 1 . The larger value of $\mathrm{R}$ indicates stronger relationship between dependent and independent variables. In this model $\mathrm{R}=0.823$, it indicates that there is strong relationship between independent variables (social factors, product quality and perceived price) and (dependent variable) consumer buying behavior.

From the ANOVA table, the estimated regression model is statistically significant $(\mathrm{F}=156.431, \mathrm{p}=.000, \mathrm{df}$ =390). Three independent variables (social factors, product quality and perceived price) have been good predictors for (dependent variable) consumer buying behavior.

The coefficient table shows the VIF data. According to Hair et al. (1995) the maximum acceptable level of VIF is 10 . If the value of VIF value over 10 is a clear signal of multicolinearity and the VIF values of social factors, product quality and perceived price are $2.628,2.192$ and 2.280 which are less than 10 which suggests that there is no problem of multicollinearity between the independent variables.

The result shows that impact of perceived price, product quality and social factors seems significant impact $(p<0.05)$ on the consumer buying behavior because the $p$-values are less than 0.05 .

From the regression equation, it is clear that every one unit change in social factors will improve by 0.431 units in consumer buying behavior, every one unit change in product quality will improve by 0.656 units in consumer buying behavior and every one change in perceived price will improve by 0.354 units in consumer buying behavior for buying television. It shows that all the independent variables are the highly influential factors for consumer buying in the buying television because the p-values is greater than 0.05 .

\section{Conclusion}

As a conclusion, this study is about the factors influencing the consumer buying behavior of television buying in the Nepalese market. Nowadays, the demand of television is rapidly increasing. Television has been a common need to the most of the people nowadays.

In this research, three important factors were chosen to investigate their effect on the consumer buying behavior. Social factors, product quality and perceived price are taken as independent variables to explore the relationship with consumer buying behavior. Correlation analysis showed that all the four independent variables (social factors, product quality and perceived price) have significant relationship with the dependent variable consumer buying behavior.

In this study, regression analysis was conducted to explore the impact of independent variables on consumer's buying behavior. The result showed that three independent variables (social factors, product quality and perceived price) have the positive and significant impact on consumer buying behavior in the buying of television in Kathmandu.

\section{Implications}

Certain limitations of this study provide opportunity for the further research. Based on the findings, there are few recommendations for the researchers in the future. First, it is recommended that the additional factors affecting variables which are not captured for this analysis must be used to know the real effect on consumer buying behavior. Additional analytical tools should be used to analyze the collected data.

Furthermore, this research can also further be undertaken on the basis of additional demographic variables. Future research could also be conducted by focusing on the similar study of consumer buying behavior with some other products.

The study suggests that television producers should pay more attention to build product quality and determination of price of the product they offer to the customers as well as social factors prospective television buyers in Nepalese market. 


\section{REFERENCES}

Aaker, D. A. (1991). Managing brand equity: Capitalizing on the value of a brand name. New York: Free Press.

Aaker, D. A. (1996). Measuring brand equity across products and markets. California Management Review, 38(3), 102-20.

Ba, S. \& Pavlou, P. A. (2002). Evidence of the effect of trust in electronic markets: Price premiums and buyer behavior. MIS Quarerly, 26(3), 243-267.

Bagozzi, R. P. \&. Warsha, A. J. (1992). Recognition and measurement of memory for print advertisements. Marketing science, 2(2). 95-134.

Bagozzi, R. P. (1979). The Role of Measurement in Theory Construction and Hypothesis Testing: Toward a Holistic Model, in Conceptual and Theoretical Developments in Marketing, Ferrell, O. C. , Brown, S. W. , and Lamb, C. W. , eds., Chicago: American Marketing, 15-33.

Bagozzi, R. P. (1992). The Self-Regulation of Attitudes, Intentions, and Behavior. Social Psychology Quarterly, (55) $178-204$.

Borden, N. (1964). The concept of the marketing mix, in Schwartz, G. (Ed.): Journal of Advertising Research, pp.2-7, John Wiley, New York.

Chang, T. Z. \& Wildt, A. R. (1994). Price, product information, and purchase intention: An empirical study. Journal of the Academy of Marketing Science, 22(1), 16-27.

Cochran, W. G. (1963). Sampling Techniques, 2nd Ed., New York: John Wiley and Sons, Inc.

Ding, H.T., F.L. Suet, S.P. Tanusina, G.L. Ca \& C.K. Gay, (2011). Dependency on Smartphone and the impact on purchase behavior, Young consumers: Insight and Ideas for Responsible Marketers, 12(3): 193 - 203.

Dodds, W. B. \& Monroe, K. B. (1985). The effect of brand and price information on subjective product evaluations. Advances in Consumer Research, 12 (1), 85-90.

Eagly, A. H. \& Chaiken, S. (1993). The psychology of attitudes. Fort Worth, TX: Harcourt Brace Jovanovich College Publishers.

Ernest, C.D.R., Moshin, B. \& Chung, Y.N. (2010). The influence of role models on young adults purchase, Faculty of Economics and Business University Malaysia Sarawak. pp: 70-81.

Farzana, W. (2012). Consumers' psychological factors association with brand equity of high involvement product: Case of laptop. World Journal of Social Sciences, 2(5): 90-101.

George, D. \& Mallery, P. (2010). SPSS for Windows Step by Step: A Simple Guide and Reference 17.0 Update. 10th Edition, Pearson, Boston.

Ghosh, A. (1990). Retail Management. Chicago: Dryden press.

Hair, J. F., Jr., Anderson, R. E., Tatham, R. L. \& Black, W. C. (1995). Multivariate Data Analysis, 3rd ed, Macmillan Publishing Company, New York.

Jacob, J. \& Olson, J. C. (1977). Consumer Response to Price: An Attitudinal, Information Processing Perspective: American Marketing Association. 73-86.

Keller, K. L. (2001). Building customer-based brand equity. Marketing Management. 10(2), 14-19.

Khan, M. (2006). Consumer Behaviour and Advertising Management. New Age International Publisher (P) ltd., New Delhi.

Kotler \& Armstrong (2010). Principle of marketing. 3th Edn., Pearson Education.

Kotler, P. \& Keller, K. (2006). Marketing Management. 12th Edition, Prentice Hall, Upper Saddle River.

Kotler, P., Armstrong, G., Wong, V. \& Saunders, J. (2008). Principles of marketing, Pearson - Harlow.

Lutz, R. (1986). Quality is as quality does: An attitudinal perspective on consumer quality judgments. Presentation to the Marketing Science Institute Trustees' Meeting, Cambridge, MA.

Monroe, K. B. \& Chapman, J. D. (1987). Framing Effects of Buyers' Subjective Product Evaluations. Association for Consumer Research, 193-197.

Nelson, M. R. \& McLeod L.E. (2005). Adolescents brand consciousness and product placement: Awareness, liking and perceived effects on self and others. International Journal of Consumer Studies, 25 (1): 1-13.

Perreau, F. (2014). The Consumer Factor. The Consumer Buying Decision Process. $\mathrm{http}: / /$ theconsumerfactor.com/en/5-stages-consumer-buying-decisionprocess/ Accessed on 29 December 2014.

Rashotte, L. (2007). Social influence. The Blackwell Encyclopedia of Sociology, 1-3. Retrieved from: https://onlinelibrary.wiley.com/doi/abs/10.1002/9781405165518.wbeoss154 (Dated: 28 December, 2018). doi:10.1002/9781405165518.wbeoss 154 .

Solomon, M., Bamossy, G., Askegaard, S., \& Hogg, M.K. (2006). Consumer Behavior: A European Perspective. Fourth Edition. Harlow: Prentice Hall.

Suki, N. M. \& Suki, N. M (2013). Dependency on Smartphone: An analysis of structural equation modeling. Journal of Technology, 62(1): 49-55.

Teng, L. (2008). A Comparison of Two Types of Price Discounts in Shifting Consumers Longevity in Risky Situations. Journal of Marketing 72, 96. 
Warshaw, P. R. \& Davis, F. D. (1985). Disentangling behavioral intention and behavioral expectation. Journal of Experimental Social Psychology, 21(3), 213-228.

Zeithaml, V. (1988). Consumer perceptions of price, quality and value: A means-end model and synthesis of evidence. Journal of Marketing, 52, 2-22. 